\title{
Lexis
}

Journal in English Lexicology

18 | 2021

Lexical learning and teaching

\section{Qualitative analyses of learners' discourse about their on productive vocabulary in spoken interactions}

Pascale Manoïlov and Nicole Divoux-Ringuette

\section{(2) OpenEdition \\ Journals}

Electronic version

URL: https://journals.openedition.org/lexis/6044

DOI: $10.4000 /$ lexis.6044

ISSN: 1951-6215

Publisher

Université Jean Moulin - Lyon 3

\section{Electronic reference}

Pascale Manoïlov and Nicole Divoux-Ringuette, "Qualitative analyses of learners' discourse about their on productive vocabulary in spoken interactions", Lexis [Online], 18| 2021, Online since 18 December 2021, connection on 21 December 2021. URL: http://journals.openedition.org/lexis/6044 ; DOI: https:// doi.org/10.4000/lexis.6044

This text was automatically generated on 21 December 2021.

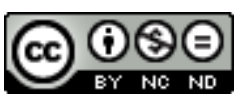

Lexis is licensed under a Creative Commons Attribution-NonCommercial-NoDerivatives 4.0 International License. 


\title{
Qualitative analyses of learners' discourse about their on productive vocabulary in spoken interactions
}

\author{
Pascale Manoïlov and Nicole Divoux-Ringuette
}

\section{Introduction}

1 Words are like the ingredients of a recipe: if you don't have eggplant, tomatoes, or onions, it is difficult to make a ratatouille. Much research in L2 communication has shown that lack of vocabulary is a serious obstacle to language learners' ability to express themselves effectively in conversational situations (Schmitt et al. [2015]).

English as a Foreign Language (EFL) learning is distinct from English as a Second Language (ESL) in the way that learners share the common language of communication of their home country. And since the necessity to use a foreign language in one's home country is usually not vital, learning a foreign language and the necessary vocabulary, at school or at university, requires both motivation and strategies to compensate for the lack of "natural" input. When it comes to using productive vocabulary (in a conversation for example), being able to access the appropriate words may also require a set of metalinguistic strategies.

3 However, since the introduction of the Communicative Approach in France in the mid-1980s, vocabulary and grammar teaching have been reduced to a minor share in both secondary and post-secondary curricula. In addition, literature and cultural studies are dominant in the language learning curriculum. Communicative activities become a pretext for studying texts or audio documents, with no real interactional stakes needed to complete a task. Vocabulary learning is not encouraged as such (Manes-Bonisseau \& Taylor [2018]), and students are given very few opportunities to acquire vocabulary that they can use in meaningful situations in class, resulting in learners having a poor linguistic repertoire. 
4 The study described here reports on a course intending to bridge the gap between vocabulary learning (and the grammar associated with lexis) and communicative taskbased instruction. The premise behind this approach is that both vocabulary input and output in meaningful situations, and relevant strategies are necessary to trigger learning. What is meant by learning is not only for students to be able to understand words but to use them appropriately when engaged in contextualized talk-ininteraction with their peers or with native speakers. Our study is based on the analysis of reflective learner diaries written during an EFL course focusing on interaction competence through a game-based approach. Our focus was to train students in communication strategies (Faerch \& Kasper [1983]; Tarone [1977], [1980]), as well as developing student-driven learning strategies. Highlighting the students' perspective, this article looks at what lexical difficulties they focus on when they are engaged in talk-in-interaction, when these difficulties occur, and what strategies are adopted to overcome them. After a review of vocabulary learning issues in contexts involving spoken interactions, we will briefly summarize the course design, based on the concepts of autonomy and games to support learning. We will then explain the methodology used to analyse the learners' diaries. Finally, the results of our analyses will be presented and interpreted in the light of the students' level.

\section{Vocabulary use in interactive games}

\subsection{Lexical competence}

5 Lexical knowledge has been given a lot of attention in pedagogical studies (Holec [1994]; Nation [2013]; Schmitt [2010b]; Webb [2020]; Webb \& Nation [2017]), since a quantifiable profile of lexical knowledge seems to be a good predictor of general language competence (Hilton [2006]; Lin \& Morrison [2010]). But what is meant by vocabulary knowledge needs to be clarified. Schmitt [2010a] considers several dimensions of lexical knowledge: spoken form, written form, meaning, grammar, collocation, register, frequency and associations. In the scientific literature, these elements are usually organised into two distinct dimensions, namely vocabulary size (i.e. number of words for which one is able to associate form to meaning), and vocabulary depth (i.e. knowledge of morphological inflexions and derivations, syntactic function, syntactic construction, semantic variation, register and context of use). "Vocabulary depth" is a much-discussed concept, but the generally-accepted list of what is involved in knowing a word is Paul Nation's [2001]: its form (spoken, written, word parts), meaning (form and meaning, concept and referents, associations), and use (grammatical functions, collocations and constraints). The latter component, word use, is associated with Halliday's concept of lexicogrammar [1961] which assumes that lexis and grammar are interrelated and form a unified system in the language. However, in studies of L2 communication, lexical knowledge is usually considered more strategic than syntactic knowledge (Quian \& Lin [2020]). For example, Llach [2011] identified lexical errors as the major factor hampering L2 learners' communication, since these errors cause communication breakdowns and disrupt the flow of speech.

6 To refine these definitions, vocabulary knowledge can also be divided in two types: receptive and productive lexical knowledge. Word recognition and semantic activation while reading or listening belong to what is called receptive knowledge. Productive 
knowledge means that words can be used expressively in their written or spoken form with their derivations, associations, and collocations in appropriate contexts. As far as L2 learning is concerned, receptive knowledge seems easier to acquire and almost always comes first (Schmitt [2010]). A major part of research concentrates on this aspect (see Yanagisawa \& Webb [2020]), while studies on productive knowledge are scarce and often look at written skills (Webb [2020]). Even when speech is transcribed, automatic analysis programmes can only provide word lists and various quantitative text measures, but they cannot assess appropriateness of use. The few studies addressing the relationship between receptive and productive word knowledge show inconsistent results. Figures range from less than half to three quarters of receptive vocabulary that is also known productively (Fan [2000]; Laufer \& Paribakht [1998] in Schmitt [2010]). Laufer [2005] found that, at the 5,000 word-frequency level, only $16 \%$ of receptive vocabulary was known productively, and the figure reaches $35 \%$ at the 2,000 level. Apart from the fact that measuring productive vocabulary knowledge is problematic, quantitative research on the subject rarely deals with the ability to recall and use vocabulary in conversational situations. This is probably due to the fact that the creation of large, transcribed corpora is very time-consuming (for example, the large-scale English Profile Project ${ }^{1}$ : it relies on the Cambridge Learner Corpus that includes $80 \%$ of written data, but only $20 \%$ of spoken data). In addition to this lack of evidence from spoken interaction, Kormos points out that L2 production is different from L1 production, since it involves more conscious metalinguistic processing, at least at the less-proficient levels. Therefore, L2 encoding frequently involves "conscious attentional control" which "can only work serially" (Kormos [2006: 166]). This problem of encoding impacts two other dimensions of vocabulary knowledge: the automaticity of use (Meara [1996]) and what $\mathrm{Gu}$ [2020:273] calls appropriateness, "the ability to know when to use what with whom in what context". In a functional-developmental, usage-based L2 teaching approach, vocabulary learning therefore implies working on knowledge, depth, automaticity and appropriateness, at both the receptive and productive levels.

7 In their efforts to broaden the scope of the characterization of lexical competence, Tremblay \& Anctil [2020] emphasize the importance of attitudes towards words and L2 word learning. Following Graves \& Watts-Taffe's [2008] work on "word consciousness", they point out the importance of "lexical sensibility" and attitudes. The latter include showing enthusiasm and motivation for learning new words, being sensitive to the contexts in which words are used, enjoying looking up information in a dictionary or enjoying playing with words and/or their sounds. From a learning point of view, these attitudes should be considered as crucial components of the learning process since they could favour the development of lexical competence.

8 Given the limited input students receive in class (on average, 18 hours per semester at universities in France), the learning of vocabulary to become an effective communicator is particularly challenging. Gu [2020] suggests that strategic learning can help learners direct their attention to the vocabulary they need to reach their goals, and allocate appropriate strategies for different dimensions of word knowledge. For example, if learners are targeting receptive or productive knowledge of a word, then their learning strategies need to be adapted. Dörnyei [2005] argues that the strategic dimension of learning should be examined as opposed to 'ordinary' learning. Additionally, Weinstein et al. [2000], cited in Tseng et al., [2006: 80], suggest that goal- 
directed, intentionally invoked and effortful learning are three characteristics of strategic learning.

Although they have been copiously researched, the identification of what a learning strategy actually is, is not entirely clear. In a synthesis of 228 meta-analyses, Hattie \& Donaghue [2016] identified almost 400 learning strategies. Among the studies analysed are those specifically dedicated to Vocabulary Learning Strategies (VLSs). These include research on "the wide spectrum of strategies used as part of an on-going process of vocabulary learning" (Gu \& Johnson [1996: 669], which are commonly elicited with surveys (Pintrich et al. [1991]; reprinted in VanderStoep \& Pintrich [2003]; Oxford [1990]; Schmitt [1997]; Tseng et al. [2006]). The methodology relies on self-report questionnaires, and the lists of strategies used do not emerge spontaneously from the learners. The reporting of some strategies is therefore questionable, since the learners' answers may be influenced by the prompts. In addition, learning strategies and their categories have been heavily influenced by Oxford's [1996] research which has since been criticised for its heterogeneity and its dependence on the American learning context (Tseng et al. [2006]). Compounded with the fact that most typologies eliciting VLSs are test- or survey-driven, one could argue that this kind of itemised typology does not fit well in learner-generated or self-regulated reflective learning contexts.

From a teaching perspective, Webb \& Nation [2017: 13-14] outline three principles to support VLSs: spending classroom time on teaching and training students (to make sure that they understand the strategies and are able to use them effectively), making students aware of the value of strategies, as well as regularly training and assessing students to ensure they understand and apply them successfully inside and outside the classroom. It is essential for students to develop effective VLSs, since the class time is highly insufficient to master the 3,000 word-families necessary to participate in most conversations and minimise lexical gaps (Adolphs \& Schmitt [2003]). Promoting strategic learning implies that students should be able to establish a self-determined path to decide which words seem most useful for their goals or needs, and how and when to learn them.

\subsection{Lexical competence and interactive games}

11 The Common European Framework of Reference for Languages (CEFR) lists five (or even six) distinctive communicative skills (or "language activities"), among which are spoken production (speaking) and interaction (spoken interaction). It is crucial here to note that using vocabulary in 'spoken interaction' is seen as fundamentally different from using it in 'speaking'. One major difference is feedback that is provided in interaction. From the perspective of the European Framework, 'speaking' implies little or no interlocutor feedback. It also implies that the act of 'speaking' has been prepared or is uttered by experts (authorities in the field, such as in political or official speeches, news delivered by a journalist, story-telling, theatre scenes or lectures) who master the subject. In such cases, thanks to prior preparation and rehearsal, all the necessary vocabulary is usually ready at hand. Conversely, in 'spoken interaction' (the term conversation will also be used in this article), speakers must constantly adjust to contingencies and the reactions of their interlocutors. The topic of the conversation may change suddenly, and it may become necessary to activate a different lexical field instantaneously. In order to maintain reasonable fluidity, words (which encode meaning) need to be activated automatically, and long reflexive pauses to search for a word should be limited to a 
minimum. Automatic language encoding processes are fundamental to the fluid flow of speech (Hilton [2008]). Therefore, taking part in a conversation implies several abilities that are impacted by vocabulary knowledge (Manoillov \& Oursel [2019]):

- Understanding what was previously said by the co-speaker;

- Adjusting to what has just been said to establish intersubjectivity;

- Adapting the ongoing flow of speech almost instantly, i.e. managing the lexicogrammatical and pragmatic dimensions of language.

12 Vocabulary plays a major role in exercising these abilities. As a listener, it is necessary to identify and recognise words in the interlocutor's speech flow and understand them in context. As a speaker, you need to access the appropriate words in memory to express your intended meaning, order these words, and adjust the choice of forms according to what came before and what comes next in the utterance. This implies that, even though providing vocabulary input surely enhances the learning of receptive vocabulary, steady practice in conversational situations seems essential for acquiring productive control of the same words. Each successful retrieval of the word will also strengthen the connection between the form of a word and its meaning (Baddeley [1990]).

13 Nation [2001] identified four strands to support vocabulary learning through teaching: after two stages concerned with input and one stage dealing with form-focused instruction, he mentions the fluency development strand. At this stage, learners do not discover new language items but this is when they should become increasingly fluent in using items they already know: "If a course does not have a strong fluency strand, then the learning done in the other three strands will not be readily available for normal use" [Nation 2013:3]. Activities promoting peer interaction therefore become necessary for fluency practice. Guided conversations and role plays have long been used in the language classroom to facilitate fluency. However, what is found in many textbooks in France often resembles controlled and artificial dialogues, without false starts, gap fillers, repetitions, overlapping, interruptions, or redirections that occur so frequently in natural conversations (Manoïlov \& Oursel [2019]). Nunan [2013] showed that although these guided interaction activities can help learners use vocabulary and structures, the type of language involved is different from what is actually used outside the classroom.

One way of engaging L2 learners in more authentic spoken interactions with their peers is to involve them in games. Dempsey et al. [1996] define games as activities driven by rules, presenting certain artificial aspects, a purpose, constraints, and consequences. When game playing in the language class, one of the major challenging constraints is using the foreign language. Atake [2003] identifies three essential characteristics of a game: rules, a purpose, and an element of pleasure. This latter element is an essential feature of classroom games, since positive emotions are believed to enhance the learning process (Fredrickson [2001], [2004]). Additionally, the interaction taking place during a game retains the essential features of natural conversation (Kasper \& Dahl [1991]). And when games are used in educational settings, they can be adapted to raise participants' awareness of specific issues - such as vocabulary use -, provide information, or trigger a change of attitude. Games can be a good source of motivation to promote the development of lexical competence, because they can prompt word discovery and consolidation through repetitions and transfer in 
meaningful contexts. In situations where learners are engaged in play, the need to activate vocabulary becomes both worthwhile and significant.

In an educational setting, games can also encourage autonomy (Cruaud [2018]). Developing learners' autonomy suggests a shift in the decision of what vocabulary should be learnt: from the teacher's choice to the learner's choice. The concept of autonomy in language learning is relevant at three levels (Littlewood [1997]; Macaro [1997]): language competence (the ability to use the language independently to communicate), learning competence (the ability to take responsibility for learning and to apply relevant strategies), and personal competence (the autonomy of choice and action). When learning vocabulary is teacher-driven, it gives little room for autonomy, and it relies mostly on extrinsic motivation (e.g. complying with the teacher's requirements or the necessity to get good grades). Holec [1981] and Benson [2003] underline the importance of creating more autonomous learning contexts for vocabulary learning improves motivation, confidence, and efficacy. Additionally, Wallace [1988] proposes that student needs and interests should be intrinsic to learning pedagogy. Therefore, granting students the power to identify what they needaccording to their previous knowledge, their goals, situations or contexts they encounter - is much more efficient.

With these considerations in mind, the following research questions are addressed:

-What are the vocabulary difficulties that students identify during their talk-in-interaction activities?

- What strategies did they use to overcome these difficulties and to enhance their learner lexicon?

- Did the strategies vary across the semester and according to their English proficiency?

\section{Data and methodology}

\subsection{The course design}

This study was conducted in the context of an EFL task-based course that targeted the development of spoken interaction through games. It was part of a first-year Master's degree program in Foreign Language Teaching Methodology (for French as a foreign language) in a university in Paris. This course was limited to 18 hours per semester in class, which represents a very limited exposure for students. Although it was not officially a Content and Language Integrated Learning (CLIL) course, it was designed to prompt experiential learning (Kolb [1984]), since the students enrolled in the course intend to become FFL teachers.

The course included board games, playing with sounds, card games, role playing, and even acting. It was designed to raise students' awareness of specific topics, such as pragmatic or linguistic skills, as well as intercultural communication. The goal was to develop students' Interaction Competence (Hall et al. [2011]) through active participation, and this meant providing students with many opportunities for meaningful peerinteractions. They were also taught strategies that could enhance the fluidity of conversations. The second goal was to trigger a self-reflective attitude towards language learning. Therefore, each game addressed specific objectives for students to focus and reflect on. Vocabulary was explicitly presented as an essential part of efficient communication, both in meaning-focused and in form-focused activities. 
Games and the interactions they triggered were aimed at transforming receptive vocabulary knowledge into productive knowledge, by necessitating the use of words in meaningful situations. The pedagogical design therefore targeted not only the development of vocabulary richness or depth (increasing the number of words in the students' repertoire), but also the productive mastery of known and new words.

Each session followed the same organisational pattern: a presentation of the learning goals, a phonological warm-up activity, the presentation of a game, a preparation phase (involving preparation of communication strategies and relevant words), the actual game, and a sharing phase (discussion of the outcomes and any difficulties encountered). Based on Nation's taxonomy of vocabulary-learning strategies (Nation [2013]), in the preparation phase, the activities were designed to have students first identify new words and then, either work on their meaning, or reactivate words they would need to participate in the games presented during the lesson. In class, vocabulary-focused activities included regular guessing games: from a list of unknown or even known words, students had to find or create definitions, in order to learn and apply reformulation strategies. To learn grammatical functions, collocations and constraints, they studied words in context, inferring regularities or irregularities from written input. For instance, they were asked to create mind maps to organise networks of meaning or rules. Particular attention was paid to fossilised or widespread errors, involving lexical register, for example. We also targeted under-used forms. They had to do with lexicogrammatical forms (compound adjectives or nouns, phrasal verbs, countable / uncountable nouns or formulaic expressions) that are fundamentally different from the French linguistic system.

In efforts to enable students to discover and explore strategies related to lexical use and learning, formal instruction was given, with a focus on how to overcome communication breakdowns (Dörnyei [1995]; Dörnyei \& Scott [1997]) due to lack of lexical knowledge. This was supported by studying videos of L1 and L2 conversations, and reading articles about strategic learning. Relevant strategies and linguistic resources were progressively added to the students' repertoire throughout the semester.

\subsection{Participants}

21 The nine students who enrolled in the course had heterogeneous profiles, in terms of age, experience and English language proficiency. Their L1 was French, except for one L1-Arabic student, who was highly proficient in French as a second language. They ranged from 21 to 51 years old, and four of them were pursuing the Master's degree as part of a career-change project. Their levels in English were quite heterogeneous: their European Framework reference level for Interaction Competence (assessed during a roleplay activity) was the following:

-A2: student 5

-B1/B1+: students 1,7 \& 8

-B2/B2+: students 2,4 \& 9

- C1: students 3 \& 6

Upon graduation, the students all intend to teach French as a foreign language and they were therefore very interested in the language learning process. They all mentioned at some stage during the semester that they had never participated in a 
game-based interactive class before, where they had fun and were able to interact with their peers over long periods of time in a stress-free context.

\subsection{Learning diaries}

The students were required to complete a digital learning diary on a weekly basis, after each of the nine two-hour sessions. This type of project, derived from ethnographic research methodology, is believed to help students unearth practical knowledge of their learning processes, providing they are guided and engage in self-reflection. Guichon [2007: 139] considers that "this type of narrative gives a certain density to the experience, and uncovers its changes over time ${ }^{20}$. Learning diaries enable the researcher to read about each student's explicit learning strategies (in the case of this study, the way they focus on words and how they decide to memorise them), and it can therefore give us some idea of how learning takes place.

The students could choose to write either in French or in English: seven chose French and two of them chiefly wrote in English. Before completing their diaries each week, the learners were asked to read an article or watch a video dealing with the subject of the weekly session. The goal of these reading or listening assignments was to raise students' awareness of the importance of learning and communication strategies. They were also meant to feed their self-reflection, develop metacognitive skills and provide them with the linguistic and conceptual tools to talk about their strategies and their own learning path. The students were informed that the diaries would be assessed and that the points of interest would be their critical thinking ability, as well as the regularity of their entries.

The topics to be entered in the diary were the same for each session, under three imposed headings:

- Summary of the session ;

- Linguistic and cultural learning outcomes \& problems, and 'hindered intended meaning' (vouloir-dire empêché);

- Self-reflection on learning outcomes and strategies.

The expression 'hindered intended meaning' is based on Yves Clot's concept of "hindered activity" (Clot [1999]), in the field of ergonomic psychology. The idea is that all activities include some impeded activity: for communication in a foreign language, hindered intended meaning would be what a speaker wanted to say but was unable to, because of a lack of (linguistic) resources.

\subsection{Methodology of the qualitative analysis}

The methodology used in this mixed-analysis study is data-driven. While reading the students' learning diaries, the issue of productive vocabulary appeared quite frequently, and could not be ignored. We therefore analysed all 76 entries $^{3}$ in the nine students' diaries (52,738 words in all). Based on Tseng et al.'s [2006] criticisms of relating to American cultural bias in Oxford's [1996] typology of learning strategies, and Byon's [2012] suggestions, we decided not to use a prescriptive list of learning strategies in our analyses. This is a rare type of study (involving a heterogeneous group of French-speaking learners of English), and the data collected is exclusively from diary 
entries and written reflections; we therefore decided that our subset of learning strategies should emerge organically from our corpus.

The analysis was carried out in two phases: a textual analysis first, followed by a thematic analysis. Using the AntConc concordancing software (Anthony [2016]), a word list was first extracted from the diaries, and we counted on an item-by-item basis the lexical field frequency from the learners' comments. Thematic groups, illustrated in Table 1, were then extrapolated from these lists.

Table 1. Semantic fields found in the students' diaries

\begin{tabular}{|l|l|l|l|}
\hline $\begin{array}{l}\text { Key words } \\
\text { (synonyms } \\
\text { included }\end{array}$ & $\begin{array}{l}\text { Number } \\
\text { occurrences }\end{array}$ & $\begin{array}{l}\text { Key words } \\
\text { (synonyms included) }\end{array}$ & $\begin{array}{l}\text { Number } \\
\text { occurrences }\end{array}$ \\
\hline Playing / Games & 440 & Group / Team & 194 \\
\hline Learning & 331 & $\begin{array}{l}\text { Interaction } \\
\text { Conversation }\end{array}$ & 189 \\
\hline Speaking & 321 & Understanding & 155 \\
\hline Vocabulary & 297 & Strategies / Reflection & 139 \\
\hline
\end{tabular}

For the purpose of intercoder accuracy, we then worked on a random sample from the diaries, which amounted to $20 \%$ of the whole corpus. We selected all the extracts where vocabulary was mentioned, to identify vocabulary-related comments as well as any mentioned learning strategies. However, given that there is little consensus on what constitutes a learning strategy (Hattie \& Donoghue [2016]), and the qualitative orientation of our study, we used qualitative data-driven methods. Taking the student entries in response to the weekly prompts (see section 2.3.) we looked at the following: 1) what vocabulary the students mentioned, 2) what vocabulary issues they reported, 3) how they dealt with vocabulary issues. We transferred all vocabulary-related comments into a spreadsheet. With further analysis, sub lists emerged (Table 2 for problems and Table 3 for strategies). The coding grid was submitted to the inter-coder agreement of three separate researchers ${ }^{4}$ who coded individually. As a next step, adjustments were made and a Cohen's Kappa test was run $(\mathrm{k}=0,88)$, before coding the whole corpus.

\section{Vocabulary-in-interaction: Results and discussion}

Our results will be presented in two main sections: the problems mentioned and the strategies used by our learners. We noted that in their session summaries, all students added vocabulary lists. We considered that writing lists of vocabulary or pointing out activities relating to vocabulary learning was a part of their strategic learning, as we explain below in section 3.2 . 


\subsection{Problems with vocabulary mentioned by the students ( 50 comments)}

of the 76 learner diary entries, fully two-thirds (50 entries) include comments describing problems with vocabulary.

Table 2. Problems reported by learners

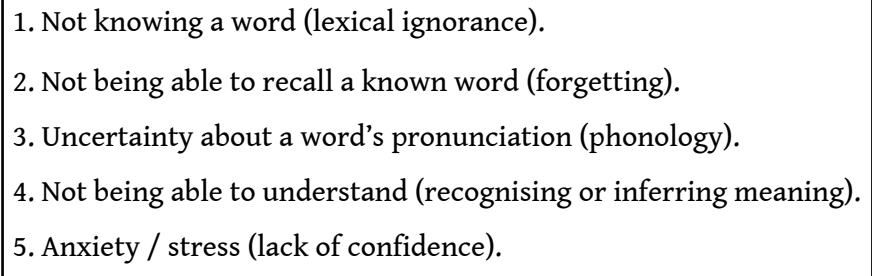

\section{Not knowing a word (lexical ignorance) - 75 comments}

The main difficulty mentioned by the learners is their inability to express what they wanted to say ('hindered intended meaning') while in interaction with their peers. Two main reasons were provided. The first one was their lack of knowledge of what they considered simple, useful words:

(1) When in interaction, I couldn't remember very simple words like "an internship" or "compulsory" or even "remember"!!, but I remembered very well much more complicated structures and words. As I am not used to speaking everyday English, I sometimes have gaps in my vocabulary. (student 6-C1)

It should be noted that all students express the need to develop their lexical repertoire to support their interaction skills. Although this could be considered to be an expressed problem, we treated it as a goal-setting strategy (see section 3.2.).

The students also express their frustration because of a disconnect between their receptive and productive lexicons. They wrote about the words they knew they could recognise, should they hear or read them, but that they were unable to produce when they needed them:

(2) On a personal note, I always have the (rather unpleasant) impression that I am in a phase of "dusting off" my English. When speaking, I am always looking for my words and when someone tells me the word, I often say to myself: 'I knew it!' Once again, I feel the lack of active practice of the language. I regularly watch films in English (admittedly with French subtitles, but I also listen a lot to what is said), but I realise that in terms of learning, this is probably too passive, at least in terms of moving up a notch in my oral expression. (student 8-B1)

The learner's lexical frustration is described as resulting from lack of practice and use of the language.

\section{Uncertainty about a word's pronunciation (phonology) - 21 comments}

Besides problems with knowledge of or recalling words, the students also mentioned their difficulties with pronunciation: 
(3) I sometimes have doubts about my pronunciation: I'm always looking for the right words and the right way to pronounce them. At the same time, I always try to "hide" my French accent. With the pressure of it all, I end up making mistakes most of the time. (student $1-\mathrm{B} 1)^{7}$

These learners may have become aware of their pronunciation problems because phonology was a point of frequent attention in their English classroom, during the lesson warm-up phase. It is interesting to note that, although the students learnt how to decipher the International Phonetic Alphabet in class, most of them did not transcribe new words in their lists (or copy and paste the phonetic transcription from the dictionary). This is probably something that would need to be explicitly taught.

\section{Not being able to understand (recognising or inferring) - 9 comments}

When it comes to receptive vocabulary in interaction, a few issues are mentioned in their diaries. Students mentioned a lack of comprehension of low-frequency words such as "aviary" or "brooch". Another example had to do with the topic of a discussion they had to record:

(4) The subject was 'Students should wear "Republican outfits" when at university.' At the beginning I was confused about the meaning of a 'Republican outfit', I had this picture in my mind of French people during the revolution time (1789) with their red hat specific to the revolutionaries and called 'bonnet phrygien'. I ended up telling myself that it might mean a uniform like a school uniform, and that I probably should not translate literally this expression, like everyone should not translate words and expression from English literally. (student 4-B2)

Some students also made remarks about their lack of understanding due to missing usual visual cues: their interlocutors' face was being covered by masks (in the Covid-19 pandemic context), or they had technical issues (deficient webcam when the course took place online). The four less proficient students $(1,5,7 \& 8)$ said they suffered from not being able to see their interlocutor's lips.

\section{Stress (lack of confidence) - 7 comments}

Some learners mentioned difficulties related to their fear of a potential lack of vocabulary or inability to understand, and the importance of being helped - one could even say 'saved' - by their interlocutor, a form of stress related to face management (Brown \& Levinson [1987]; Goffman [1955]):

(5) When it came to speaking, what was most difficult for me was to dare, to dare to speak without fear of making a mistake, of having to search for my words, of not knowing how to make myself understood or of finding myself with a partner unable to help me. (student 1-B1) ${ }^{8}$

In addition to writing about the problems they had to deal with, our learners also reported on how they dealt with various vocabulary issues.

\subsection{Vocabulary learning strategies}

The following strategies were found in the diaries. Altogether, 40 different types of strategies were mentioned, with 208 mentions of strategic behaviour altogether. 
Table 3. Vocabulary Learning Strategies (VLSs) mentioned in learning diaries

\begin{tabular}{|c|c|}
\hline Discovery strategies & $\begin{array}{l}\text { 1. Writing down new words or formulaic expressions. } \\
\text { 2. Using a monolingual or bilingual dictionary to look-up for } \\
\text { meaning. } \\
\text { 3. Using a toolbox (provided by teacher) to discover new words } \\
\text { or expressions. } \\
\text { 4. Discovering new words or expressions in the dictionary. } \\
\text { 5. Noting common/important words for later look-up. } \\
\text { 6. Guessing word meaning from context. } \\
\text { 7. Looking up words found in everyday life. } \\
\text { 8. Watching } \mathrm{TV} / \text { film/series in English/with English subtitles. }\end{array}$ \\
\hline Memorisation strategies & $\begin{array}{l}\text { 1. Writing words down over and over. } \\
\text { 2. Reviewing words repeatedly over time (rote memorization). } \\
\text { 3. Writing lists of words over and over. } \\
\text { 4. Reviewing words or with others. } \\
\text { 5. Describing words. } \\
\text { 6. Using specific words over and over to memorise them. } \\
\text { 7. Noticing and remembering words through common } \\
\text { expressions/idioms. }\end{array}$ \\
\hline Consolidation strategies & $\begin{array}{l}\text { 1. Listening carefully for lexical information (relying on the } \\
\text { nature of words). } \\
\text { 2. Watching TV/film in English without subtitles. } \\
\text { 3. Listening to the radio in English. } \\
\text { 4. Speaking as much as possible. } \\
\text { 5. Using known words even though unstable knowledge. } \\
\text { 6. Using cognates. } \\
\text { 7. Making up new sentences with recently learnt words. } \\
\text { 8. Explaining and giving examples. } \\
\text { 9. Describing word meaning without saying the word itself } \\
\text { (circumlocution, paraphrasing). }\end{array}$ \\
\hline
\end{tabular}




\begin{tabular}{|c|c|}
\hline $\begin{array}{l}\text { Semantic and metalinguistic } \\
\text { strategies }\end{array}$ & $\begin{array}{l}\text { 1. Organizing words into lists and semantic groups. } \\
\text { 2. Organising words using language rules (with mind maps). } \\
\text { 3. Associating salient contexts (story/action/emotion) to word. } \\
\text { 4. Connecting sentence context to words found in them. } \\
\text { 5. Connecting words to antonyms or synonyms. } \\
\text { 6. Connecting written forms of word with pronunciation } \\
\text { (phonemic transcription). } \\
\text { 7. Contrasting L1/L2. } \\
\text { 8. Reflecting on previously known words and transfers. } \\
\text { 9. Reflecting on errors, sounds or morphology of words. } \\
\text { 10. Reflecting on the use of relevant VLSs. } \\
\text { 11. Abandoning non-relevant strategies. } \\
\text { 12. Criticizing former strategies. }\end{array}$ \\
\hline Interactive strategies & $\begin{array}{l}\text { 1. Asking others about word knowledge. } \\
\text { 2. Helping others with vocabulary. } \\
\text { 3. Providing, receiving or requesting corrective feedback to/ } \\
\text { from peers or teacher. } \\
\text { 4. Practicing the language in interaction. }\end{array}$ \\
\hline
\end{tabular}

\section{Discovery strategies - 56 comments}

The most common discovery strategy students referred to is the use of dictionaries, or the vocabulary toolboxes provided in class. All of our learners wrote lists of words, ranging from 4 or 5 words to over 90 words, on a weekly basis. The long lists were not common in the diaries (8 mentions), but we do not know the length of lists students might have created in their personal notebooks. In addition to various types of vocabulary lists (such as translations, English and/or French dictionary definitions), our learners also used other strategies to enhance their lexical repertoires. In class, they had been advised to use a specific learners' dictionary, ${ }^{9}$ to make sure that any definitions they worked with were easily understandable. The learners therefore used monolingual dictionaries to understand words or to recall meaning, as well as the toolboxes provided in class. These include formulaic language such as collocations and idiomatic expressions. Awareness-raising activities were carried out in class on this important subject. This is one student's reaction to the use of a toolbox:

(6) The worksheet provided in the previous session was very useful again. I used it to express my opinion. Sometimes I agreed with what my classmates said, in which case I used "I agree with you 100 percent" or "I couldn't agree more". If I disagreed, I used "That might be true but I beg to differ" or "I'm not so sure about that". (Student 3-C1) ${ }^{10}$

\section{Memorisation strategies - 27 comments}

Our nine learners' vocabulary lists took various forms: English words with translations in French and/or definitions in English, the latter being either personal or (in most cases) copied from an online dictionary. Some students also said that they created lists in paper notebooks or digital files. These lists were student-driven and based on words they found interesting and/or useful, and wanted to remember. 
In efforts to acquire and use new vocabulary in context, learners applied varied techniques ranging from rote memorization to describing. One learner in particular (student 5), acknowledging being the least proficient speaker in the target language, said the following:

(7) I have to admit that I'm not very good at rote learning and I try to find other methods to memorise the lexicon: I try for example to reread my word list at least once a week to be able to remember it, and I try to compose simple sentences with these words to be sure I remember them. (Student 5A2) ${ }^{11}$

Students also pointed out the necessity of steady practice (repetition and recall) and of using new vocabulary to support its acquisition. They more specifically mentioned the need for repetition and regular reactivation to store vocabulary in their long-term memory. In the following quote, student 9 writes about a role-play activity (Class 3), in which numerous rehearsals of their 'script' gradually enhanced fluidity:

(8) The game was quite immersive and I think I spoke more naturally, without any filter, towards the end than at the beginning. I also learnt my own story better and better, and I mastered my "text" better and better as the repetitions went on. (Student 9-B2) ${ }^{12}$

\section{Consolidation strategies - 55 comments}

Our learners used dictionaries for various word-learning activities. The way they often defined unknown words in English, either in their own words or using a dictionary definition (rather than just translating them), suggests that focusing on the meaning of a new word may help them memorise it. Student 5 (A2) explains the process:

(9) I try to re-read words and try to explain them in my own words to check if I understand the meaning. Then I look up the definition in the dictionary and its pronunciation to check my understanding of the meaning and I correct the spelling and the pronunciation. Then I try to memorise the definition. If I see that it's complicated to memorise that, then I try to express it in another way so that I can fix the overall meaning in my mind, and reuse it in my future interactions. (Student 5-A2) ${ }^{13}$

Here is an example of the definitions she wrote down in her diary to memorise the word enemy (which a transparent word for French speakers). Part (1) is the definition created by the student, and (2) is the dictionary definition:

(10) An enemy:

1- Someone who hate you or you are in conflit with him.

2- /'enəmi/ a person who hates somebody or who acts or speaks against somebody /something.

This example (out of ten that were written the week this activity was practiced in class) demonstrates the student's strong commitment to her learning. It is interesting to note that this student wrote definitions of transparent or frequent words, such as enemy, dragon or ghost ${ }^{14}$, along with less common ones, such as axe, miserly or broom (the latter being an infrequent word for students learning English in a French institutional setting). She practiced rephrasing at home, and became more proficient in classroom interaction with her peers. When confronted with communication breakdowns, being able to paraphrase or provide explanations or synonyms are efficient achievement strategies (Nakatani [2010]). Although the definition provided by the student 
(definition $n^{\circ} 1$ ) contains a few errors, defining or exemplifying words seem good ways to create networks of meaning.

In line with this, all students (from A2 to $\mathrm{C} 1$ ) mentioned the use of mixed strategies, ranging from initial stages of word discovery to consolidation techniques:

(11) I tried to somehow guess the name of what I wanted to say for each card. For example: 5 of Hearts for the " 5 de coeur" or even the Queen/King of Hearts for "les reines et rois de". But I found the others a little more difficult. This is why I resorted to an online dictionary, then I copied them into my notebook to be able to remember them. After the two hours spent in class, I took a couple of random cards and I practiced describing them. I did the same thing the next day and a couple of days after the course to be sure that I remembered it in the long term. (Student $3-\mathrm{C} 1)^{15}$

In contrast to the sort of data that can be collected through VLS questionnaires - which artificially separate learning strategies - we found that our learners did not separately tabulate their efforts to acquire vocabulary in their weekly reflections. Instead, they described the strategy used relating to vocabulary use and acquisition as an intertwined holistic process.

Semantic and metalinguistic strategies (Grouping words, creating networks and mind maps) - 35 comments

Explanations provided by students in their diaries enable us to understand both the way they process information and how they potentially store words in their memory or what difficulties they encounter in their interlanguage.

The students also realised that comprehension problems could be due to a lack of compensation strategies:

(12) After completing the "oral communication strategy self-assessment," I realised that I had never realized I should focus on the verb and the subject of the sentence to understand the general idea; I always try to understand the whole sentence. I also don't explicitly encourage the person I'm talking to to slow down or use easier words. (student 9-B2) ${ }^{16}$

Here, student 9 is referring to Nakatani's Oral Communication Strategy Inventory (Nakatani [2006]), which the students worked on in class. This comment (example 12) by a student at the B2+ level illustrates her realization that strategies can be useful in overcoming communication breakdowns.

Form-focused activities completed in class led to interesting explanations of how words should be classified, and how lexicogrammatical rules inferred by students could help with their productive knowledge of the English lexicon:

(13) I learnt that there was another category I have never seen or heard the name of before: it was "collective nouns". They are a collection of things or a number of people. For example "a group", "a crew", "a class" etc., are collective nouns. The word "luggage" is uncountable and during the game I used to say "luggages", and we say "the luggage is" and not 'are', "there is luggage" and not "there are luggages" ". We can only say "one piece of luggage", "six pieces of luggage". (Student 4-B2)

This comment shows that the student got interested in the subject of countable / uncountable nouns, because she needed to produce such words and wanted to avoid 
further errors. Not only did she write about the words' morphology, but she also reflected on their grammatical constraints.

Another interesting comment from a student refers to a meta-lexical activity (on compound adjectives) done in class, in which the learners studied a corpus of short texts and had to infer lexicogrammatical rules. Student 5 remarked a better comprehension of structural rules governing adjective composition because she identified rule patterns herself (instead of simply learning the rules and applying them blindly). The student remarked that this activity provided her with a new learning strategy:

(14) In fact, I was able to retain the rule of compound adjectives which is the following: the compound adjective is generally composed of two elements. The first element serves to specify the meaning of the second. This second element is a past participle in the examples cited above. The first part of compound adjectives is not complicated to remember. It is the second part that I try to remember in order to be able to compose several adjectives: For example: You can combine 'badly' or 'well' with 'timed' to create two different adjectives. (Student $5-\mathrm{A} 2)^{17}$

Even though the 'phrasing' is idiosyncratic, this autonomous rule-inferring technique demonstrates the learner's realization that this new decoding strategy (and subsequent lexicogrammatical knowledge) can be integrated into her emerging linguistic system. Inferring and organising knowledge about vocabulary seems to have helped the students. For example, a mind-map activity was carried out in class and the learners seemed to find this quite useful:

(15) In my group, we had to prepare a mind map on compound nouns to be able to explain how to form them to the other students. Making the mind map helped me understand and set clear the rules of how to form them and how to understand them and not get confused since there are compound nouns that are composed with the same words but in different order. (Student 4-B2)

Manipulating words according to lexicogrammatical rules or lexical fields helped the students organise their learning, especially since they had to provide explanations to their peers prior to executing some game-play activities (section 2.1.) organised in workshops.

Finally, a contrastive approach, in which students compared French with English, also emerged in the data. Comparing the two languages enabled the students to notice similarities and differences, and to concentrate on specific topics.

\section{Interactive strategies - 35 comments}

Meaningful interactive situations while playing games and interacting with peers seemed to aid in vocabulary recall:

(16) In talking to and listening to others [classmates], I was able to expand my vocabulary. (Student 1-B1) ${ }^{18}$

Vocabulary use in interaction also appeared to challenge the most proficient students as it was highly dependent on situations, subject matters and locutors, prompting learners to adapt to their interlocutors. 
(17) Changing playing tables was very interesting: not only you had to re-use the game vocabulary, but you had to adapt to different language levels

(Student 2-C1)

\subsection{Developing attitudes and motivation}

49 We also explicitly worked on a set of strategies and methodologies to develop positive learner attitudes, and motivation for lexical learning. These included goal setting, planning for individual learning, raising awareness of the usefulness of practice, reflecting on stress or anxiety resulting from lexical difficulties, as well as on positive feelings related to successful lexical learning, and expressing self-esteem related to vocabulary knowledge and use.

Acquiring efficient vocabulary learning strategies also helped students to develop their autonomy and their motivation for English. They all mentioned at some stage in their diaries (37 comments in all) that they went beyond the course when it came to vocabulary learning:

(18) This morning, on my way to work, I saw frost on the windshield of a car, so I asked myself 'How do you say windshield in English?' After I got home, I looked up how to say the word in English in the Oxford Learner's Dictionary. (Student 9-B2) ${ }^{19}$

51 Adopting new autonomous learning strategies and having the opportunity to reflect on them seems to have enhanced the students' intrinsic motivation to learn more vocabulary and to develop their lexical competence, even outside class hours:

(19) This course has allowed me to sort out the learning techniques that make me learn best: the technique of learning through games is definitely one of them. We are autonomous, it stimulates us and makes us learn while having fun. And in the long run, I noticed that being aware of my mistakes, whether by myself or by a peer, helped me remember the corrections better afterwards. (Student 3-C1) ${ }^{20}$

52 Our learners often mentioned moments of linguistic awareness in their learning diaries: events in class or reflections on their own, where they learned or were able to self-correct something they had never learnt or understood before. These are salient experiences for our learners. Frequent comments were made on what the learners discovered about the English pronunciation of words they thought they knew. For example, one student explained how the letter $\langle\mathrm{w}\rangle$ should not be pronounced in the word 'who' (/hu:/), although he was pretty sure he had never been corrected on his pronunciation before, and had never noticed the absence of the sound /w/ in listening.

53 Finally, our students' interest in discovering new word forms encouraged them to study vocabulary at home, and to explore the language further. For instance, while looking in a dictionary, five students mentioned that they discovered more formulaic phrases or synonyms this way, and that they wrote them in their journals and then learnt them.

54 All the above comments echo the conclusions formulated by other researchers: intentional, purposeful learning leads to more robust and faster learning (Schmitt [2008]). Finally, it should be noted that all our learners commented on their development of strategies and attitudes to an equal extent, with the exception of 
student 5 (A2 level), whose diary entries contained twice as many mentions of vocabulary learning strategies.

\section{Conclusion} They displayed interest in understanding word constructions, collocations or lexicogrammar. They actually enjoyed looking up words in a dictionary and felt creative when building up their own vocabulary lists (including collocation, synonyms, and contextualized examples). They explained how they took pleasure in playing with words, both high and low-frequency, and with formulaic language. Furthermore, a change in their attitudes, brought about by metalinguistic exploration of words in context and strategies for word learning (setting goals, interacting and happily experimenting with lexis in context), also gave rise to greater interactive willingness and confidence. The learners themselves attributed this attitude shift (in addition to greater confidence and a sense of self in the target language) to having a greater 
mastery of vocabulary, having acquired more automatic access to their lexical repertoire (thanks to learner-driven tools), and selecting the 'correct' vocabulary in interactional contexts. Additionally, they expressed a better command of compensatory strategies to overcome communication breakdowns: adapting the language to other learners to ensure comprehension, paraphrasing, etc. Again, regardless of their initial proficiency level, all learners expressed happiness in being able to develop vocabulary-building skills that they had not used in former language classes (both explicitly taught skills, and those they developed on their own). They considered that the techniques they learned in class and the strategies they chose enhanced their vocabulary learning. This was especially true for the A2 student, who seemed to have developed her learning immensely.

This qualitative study is admittedly limited in scope, and we have only scratched the surface of the complexity of vocabulary development, or reflection on and development of autonomous vocabulary learning strategies. A larger participant sample and quantitative analyses of the data associated with this qualitative analysis will be avenues to explore. Specifically, focusing on the combination of strategies selected by individual learners, and their relationship to overall success in lexical learning and use would also reveal interesting perspectives on this same data set.

\section{BIBLIOGRAPHY}

ADOLPHS Svenja \& SCHMITT Norbert, 2003, "Lexical coverage of spoken discourse”, Applied Linguistics, Volume 24, 425-438.

ANTHONY Laurence, 2016, AntConc (Version 3.4.4) [Macintosh OSX 10.11.4], Tokyo, Japan, Waseda University: http://www.laurenceanthony.net/

ATAKE Kasuko, 2003, "Using games to teach English in a Japanese junior high school", ERIC Document nED47948.

BADDELEY Alan, 1990, “The development of the concept of working memory: Implications and contributions of neuropsychology", in VALLAR G. \& SHALLICE T. (Eds.), Neuropsychological impairments of short-term memory, Cambridge University Press, 54-73.

BENEDICT Helen, 1979, “Early lexical development”, Journal of Child Language, Volume 6, 183-200.

BENSON Phil, 2003, "Learner autonomy in the classroom", in NUNAN D. (Ed.), Moving towards autonomy' in Developing student autonomy in Learning, New York: Nichols Publishing, 289-308.

BROWN Penelope \& LEVINSON Stephen C., 1987, Politeness: Some universals in language usage, Cambridge: Cambridge University Press.

CLOT Yves, 1999, La fonction psychologique du travail, Paris : PUF.

COUNCIL OF EUROPE, 2001, Common European Framework of Reference, Council of Europe.

COUNCIL OF EUROPE, 2018, Common European Framework of Reference, Companion Volume with New Descriptors, Council of Europe. 
DECI Edward L. \& RYAN Richard M., 2008, "Self-determination theory: A macrotheory of human motivation, development, and health", Canadian Psychology/Psychologie Canadienne, Volume 49, $n^{\circ} 3,182-185$.

DEMPSEY John V., LUCASSEN Barbara \& RAMUSSEN Karen, 1996, “The instructional gaming literature: Implications and 99 sources", Technical Report n96-1, University of South Alabama.

DESLAURIERS Jean-Pierre,1991, Recherche qualitative : guide pratique, Chenelière/McGraw-hill.

DÖRNYEI Zoltán, 2005, The Psychology of the Language Learner: Individual Differences in Second Language Acquisition, Mahwah, NJ: Lawrence Erlbaum.

ELLIS Rod, 2003, Task-based Language Learning and Teaching, Oxford: Oxford University Press.

FAERCH Claus \& KASPER Gabriele, 1983, Strategies in interlanguage communication, London: Longman.

FRANTZEN Diana, 2010, “Evidence of Incremental Vocabulary Learning in Advanced L2 Spanish

Learners", in CHACÓN-BELTRÁN Rubén, ABELLO-CONTESSE Christián \& TORREBLANCA-LÓPEZ María del Mar (Eds.), Insight into Non-Native Vocabulary Teaching and Learning, Bristol, Buffalo, Toronto: Multilingual Matters, 126-144.

FREDRICKSON Barbara L., 2001, “The role of positive emotions in positive psychology: The broadenand-build theory of positive emotions", American Psychologist, Volume 56, n³, 218-226.

FREDRICKSON Barbara L., 2004, “The broaden-and-build theory of positive emotions", Philosophical Transactions of the Royal Society B: Biological Sciences, 359 (1449), 1367-1377.

GOFFMAN Ervin, 1955, “On Face-Work: An analysis of ritual elements in social interaction”, Psychiatry: Journal of Interpersonal Relations, Volume 18, n³, 213-231.

GRAVES Michael \& WATTS-TAFFE Susan, 2008, "For the Love of Words: Fostering Word Consciousness in Young Readers", The Reading Teacher, Volume 62, n³, 185-193.

GU Peter Y., 2020, “Strategies for Learning Vocabulary”, in wEBB Stuart (Ed.), The Routledge Handbook of Vocabulary Studies, London \& New York: Taylor \& Francis, 271-287.

GUICHON Nicolas, 2007, « Récits de soi en formation : L'écriture réflexive dans la formation didactique des enseignants ", Présenté à Récits de soi en formation, Tours : France, 136-145. HALL Joan K., HELLERMANN John, \& PEKAREK DOEHLER Simona, 2011, L2 Interactional Competence and Development, Multilingual Matters.

HALLIDAY Michael, 1961, "Categories of the theory of grammar", Word, Volume 17, n³, 241-292. HALLIDAY Mark A. K., 2003, On Language and Linguistics, Jonathan Webster, London: Continuum. HATTIE John \& DONOGHUE Gregory, 2016, “Learning strategies: a synthesis and conceptual model”, npj Science Learn, Volume 1, Article $\mathrm{n}^{\circ} 16013$

HILTON Heather, 2006, «Quelques aspects de la mémoire verbale en L2 », Recherche et pratiques pédagogiques en langues de spécialité. Cahiers de l'Apliut, Volume XXV, n², 44-60.

HILTON Heather, 2008, "The link between vocabulary knowledge and spoken L2 fluency", Language Learning Journal, Volume $36, \mathrm{n}^{\circ} 2,153-166$.

HOLEC Henry, 1979, Autonomie et apprentissage des langues étrangères, Hatier.

HOLEC Henry, 1981, Autonomy and Foreign Language Learning, Oxford: Pergamon.

HOLEC Henry, 1994, «Compétence lexicale et acquisition / apprentissage », Cahiers de l'ASDIFLE, Volume 6, Présenté à Lexique et didactique du français langue étrangère, Paris, 1-8. 
HOLEC Henry, 1996, "Self-directed learning: an alternative form of training”, Language Teaching, Volume 29, $\mathrm{n}^{\circ} 2,89-93$.

коLв David A., 1984, Experiential Learning: Experience as the Source of Learning and Development, Englewood Cliffs, NJ: Prentice-Hall.

KASPER Gabriele \& DAHL Merete, 1991, "Research methods in interlanguage pragmatics", Studies in Second Language Acquisition, Volume 12, 215-247.

KORMOS Judit, 2006, Speech Production and Second Language Acquisition, Mahwah, NJ: Erlbaum.

KUSHKIEV Plamen, 2019, "The Role of Positive Emotions in Second Language Acquisition: Some Critical Considerations", Mextesol Journal, Volume 43, n4.

LABONTEE Richard, 2019, "Questionnaire instrumentation for strategic vocabulary learning in the Swedish as a second language learning context", Studies in Second Language Learning and Teaching, Volume $9, \mathrm{n}^{\circ} 2,313-249$.

LAUFER Batia, 2005, "Focus on form in second language vocabulary learning”, EUROSLA Yearbook 5, 223-250.

LIM G. S. \& GALACZI Evelina D., 2010, "Lexis in the assessment of Speaking and Writing: An illustration from Cambridge ESOL's General English tests”, Cambridge ESOL: Research Notes, Volume 41, 14-26.

LIN Linda \& MORRISON Bruce, 2010, “The impact of the medium of instruction in Hong Kong secondary schools on tertiary students' vocabulary", Journal of English for Academic Purposes, Volume 9, 255-266.

LITTLE David, 2007, “Language learner autonomy: Some fundamental considerations revisited", Innovation in Language Learning and Teaching, Volume 1, $\mathrm{n}^{\circ} 1,7-29$.

LITTLEWOOD William, 1997, “Self-access: Why do we want it and what can it do?", in BENSON Phil \& VOLLER Peter (Eds.), Autonomy and Independence in Language Learning, 79-92.

MACARO Ernesto, 1997, Target language, collaborative learning and autonomy, Clevedon: Multilingual Matters.

MANES-BONISSEAU Chantal \& TAYLOR Alex, 2018, Propositions pour une meilleure maitrise des langues vivantes étrangères, Oser dire le nouveau monde, Paris: Ministère de l'éducation nationale.

MANOÏLOV Pascale, 2019, « Repenser l'organisation des tâches pour favoriser le développement des interactions orales entre pairs », Les Langues Modernes, Volume 3, 18-27.

MANOÏLOV Pascale \& OURSEL Élodie, 2019, « Analyse des interactions et didactique des langues : tour d'horizon des relations ", Linx. Revue des linguistes de l'université Paris Nanterre, [En ligne] Volume 79, mis en ligne le 30 décembre 2019, URL : http://journals.openedition.org/linx/3399 MILTON James, 2010, “The development of vocabulary breadth across the CEFR levels", in BARTNING Inge, MARTIN Maisa \& VEDDER Ineke (Eds.), Communicative proficiency and linguistic development: Intersections between SLA and language testing research, Eurosla Monographs Series, 1, 211-232. NAKATANI Yasuo, 2006, "Developing an oral communication strategy inventory", The Modern Language Journal, Volume 90, ${ }^{\circ} 2,151-168$.

NAKATANI Yasuo, 2010, “Identifying strategies that facilitate EFL learner's oral communication: A classroom study using multiple data collection procedures”, The Modern Language Journal, Volume 94, 116-136. 
NATION I. S. Paul, 2001, Learning Vocabulary in Another Language, Cambridge, UK: Cambridge University Press.

NATION I. S. Paul, 2013, Learning Vocabulary in Another Language, $2^{\text {nd }}$ edition, Cambridge: Cambridge University Press.

NUNAN David, 2013, Learner-Centered English Language Education, New York, N.Y.: Routledge.

OXFORD L. Rebecca, 1996, Language Learning Strategies: What Every Teacher Should Know, New York: Newbury House.

OXFORD L. Rebecca, 2011, Teaching and Researching Language Learning Strategies, Harlow, GB: Pearson Education.

PEARCE Michael, 2006, The Routledge Dictionary of English Studies, London: Taylor \& Francis.

QIAN David \& LIN H. F. Linda, 2020, “The Relationship Between Vocabulary Knowledge and Language Proficiency", in WEBB Stuart, The Routledge Handbook of Vocabulary Studies, London \& New York: Taylor \& Francis, 66-80.

RICHARD C. Jack \& TAYLOR Andrew, 1992, "Defining strategies in folk definitions", Working Papers of the Department of English, City Polytechnic of Hong Kong, Volume 4, n², 1-8.

RITTTERFELD Ute, CODY Michael \& VORDERER Peter, 2009, Serious games, Mechanisms and effects, NewYork: Routledge.

SCHMITT Norbert, 2008, "Review article: Instructed second language vocabulary learning", Language Teaching Research, Volume 12, n³, 329-363.

SCHMITT Norbert, 2010a, "Key Issues in Teaching and Learning Vocabulary”, in CHACÓN-BELTRÁN Rubén, ABELLO-CONTESSE Christián \& TORREBLANCA-LóPEZ María del Mar (Eds.), Insight into Non-Native Vocabulary Teaching and Learning, Bristol, Buffalo, Toronto: Multilingual Matters, 126-144.

SCHмIтT Norbert, 2010b, Researching Vocabulary, London: Palgrave MacMillan.

SCHMITT Norbert, 2014, "Size and Depth of Vocabulary Knowledge: What the Research Shows: Size and Depth of Vocabulary Knowledge", Language Learning, Volume 64, n4, 913-951.

SCHMITT Norbert, СOBB Tom, HORST Marlise \& SCHмITT Diane, 2015, "How much vocabulary is needed to use English? Replication of van Zeeland \& Schmitt (2012), Nation (2006) and Cobb (2007)", Language Teaching, Volume 50, n², 212-226.

TARONE Elaine, 1977, “Conscious communication strategies in interlanguage: A progress report”, in BROWN H. Douglas, YORIO Carlos Alfredo \& CRYMES Ruth H. (Eds.), On TESOL 77: Teaching and Learning English as a Second Language, Washington D.C.: TESOL, 194-203.

TARONE Elaine,1980, "Communication strategies, foreigner talk, and repair in interlanguage studies", Language Learning, Volume 30, 417-431.

TREMBLAY Ophélie \& ANCTIL Dominic, 2020, « Introduction - Recherches actuelles en didactique du lexique : avancées, réflexions, méthodes ", Lidil. Revue de linguistique et de didactique des langues, Volume 62, novembre, consulté à l'adresse http://journals.openedition.org/lidil/8322 TSENG Wen-Ta, DÖRNYEI Zoltán \& SCHMITT Norbert, 2006, “A New Approach to Assessing Strategic Learning: The Case of Self-Regulation in Vocabulary Acquisition”, Applied Linguistics, Volume 27, $\mathrm{n}^{\circ} 1,78-102$.

VAN GEERT Paul, 1994, Dynamic systems of development: Change between complexity and chaos, Harvester Wheatsheaf. 
WEBB Stuart, 2020, The Routledge Handbook of Vocabulary Studies, London \& New York: Routledge/ Taylor Francis.

WEBB Stuart, \& NATION I. S. Paul, 2017, How Vocabulary is Learned, Oxford: Oxford University Press. WEINSTEIN Claire Elen, HUSMAN Jenefer \& DIERKING Douglas R., 2000, "Self-regulation interventions with a focus on learning strategies”, in BOEKAERTS M., PINTRICH P. R. \& ZEIDNER M. (Eds.), Handbook of Self-Regulation, San Diego: Academic Press.

YANAGISAWA Akifumi \& WEBB Stuart, 2020, "Measuring Depth of Vocabulary Knowledge”, in WEBB Stuart (Ed.), The Routledge Handbook of Vocabulary Studies, London \& New York: Taylor \& Francis, 371-386.

\section{APPENDIXES}

\section{Appendix for classroom methodology}

List of games used in class (these games were adapted to educative purposes)

THIAGARAJAN S., 2006, Barnga - A Simulation Game on Cultural Clashes, Intercultural Press.

Once Upon a Time, $3^{\text {rd }}$, Atlas Games.

\section{List of input (articles and videos) on metacognition provided to students}

BROWN S., 2011, Doodlers, unite! TED2011.

DAVIES B., 2019, How Do We View Each Other?, Future Learn, University of Leeds.

DAVIES B., 2019, What Is Being Polite?, Future Learn, University of Leeds.

FAUCETTE P., 2001, “A pedagogical perspective on communication strategies: benefits of training and an analysis of English language teaching materials", Second Language Studies, 19.2, 1-40.

LITTLE David, 1995, "Learning as dialogue: the dependence of learner autonomy on teacher autonomy", System, Vol. 23, n², 175-181.

MING L., 2020, "An examination of two major constructs of cross-cultural competence: Cultural intelligence and intercultural competence", Personality and Individual Differences, 164.

SPADA N. \& LIGHTBOWN P.M., 2008, “Form-Focused Instruction: Isolated or Integrated?”, Tesol Quaterly, 42/2, 181-207.

\section{NOTES}

1. The English Profile Programme investigates learner vocabulary in the Cambridge Learner Corpus, through corpus research, in order to identify the lexical components of the six different Common European Framework of Reference (CEFR) levels.

2. «Le récit permettrait ainsi de restituer l'épaisseur de l'expérience, d'en saisir ses méandres dans sa temporalité »

3. There are 76 entries instead of 81 as some students missed some classes.

4. The two authors and Dr Agnès Leroux. 
5. "Je ne me souvenais plus, en interaction de mots très simples comme "un stage" ou "obligatoire" ou même "se souvenir" !!, mais je me souvenais très bien de structures et mots bien plus compliqués. Étant donné que je n'ai plus l'habitude de parler l'anglais courant, il m'arrive d'avoir des trous de vocabulaire très simple. " All translations from the learner diaries are by the authors, with original text quoted in these footnotes. When no footnote is given, it means that the text being quoted was written in English.

6. «D'un point de vue personnel, j'ai toujours l'impression (assez désagréable) d'être dans une phase de "dépoussiérage" de mon anglais. En effet, je cherche mes mots à l'oral, et lorsqu'on me les souffle, je me dis souvent intérieurement: “je le savais!". Je ressens encore une fois le manque de pratique active de la langue, car je regarde régulièrement des films en anglais (certes sous-titrés en français, mais j'écoute beaucoup ce qui est dit également), mais je m'aperçois qu'en terme d'apprentissage, cela est sans doute trop passif, en tout cas dans l'optique de passer un cap en expression orale».

7. «Il m'arrive par moment d'avoir des doutes sur ma prononciation, je cherche toujours les bons mots et la bonne façon de les prononcer. J'essaye par la même occasion de toujours "cacher" l'accent français. Avec la pression que me procure tout cela je fini la plupart du temps par faire des erreurs ".

8. «Ce qui était le plus difficile pour moi à l'oral était d'oser, d'oser prendre la parole sans craindre de me tromper, de devoir chercher mes mots, de ne pas savoir me faire comprendre ou de me retrouver devant un interlocuteur dans l'incapacité de m'aider $"$.

9. According to Webb \& Nation [2017], monolingual learners' dictionaries limit the definitions to the 3,000 most frequent words.

10. «La feuille fournie durant la séance précédente s'est avérée encore très utile, je l'ai utilisée comme appui afin d'exprimer mon opinion. J'étais quelque fois d'accord avec ce que disais mes camarades, dans ce cas j'utilisais 'I agree with you 100 percent' ou encore 'I couldn't agree more'. Dans le cas où je n'étais pas d'accord, j'employais 'That might be true but I beg to differ' ou alors 'I'm not so sure about that' ".

11. "J'avoue que je ne suis pas très douée pour apprendre par cœur et j'essaye de trouver d'autres méthode pour fixer le lexique: J'essaye par exemple de relire ma liste de lexique au moins une fois par semaine pour pouvoir m'en souvenir, essayer de composer des phrases simples avec ces mots pour les fixer $»$.

12. «Le jeu donnait lieu une certaine immersion et je crois que je parlais plus naturellement, sans filtre, vers la fin que vers le début. Ajoutons à cela que je connaissais de mieux en mieux ma propre histoire, et mon "texte" au fur-et-à-mesure des répétitions ».

13. "J'essaye de relire le lexique, essayer de l'expliquer avec mes propres mots si j'ai compris le sens. Ensuite je cherche la définition dans le dictionnaire ainsi que sa prononciation pour vérifier si j'ai bien compris le sens et corriger l'orthographe et la prononciation. Puis, j'essaye de retenir la définition par cœur. Si je vois que c'est compliqué de le retenir par cœur, j'essaye, dans ce cas de l'exprimer autrement pour pouvoir fixer le sens global et le réutiliser dans mes interactions futures ".

14. Although the word "ghost" is not frequent in everyday conversations, it is present in popular culture. All students know the film Ghost with Patrick Swayze and Woopy Goldberg and therefore know the meaning of this word.

15. "J'ai essayé de le deviner en quelque sorte en disant le nom de ce que je voyais sur chacune d'entre elles. Exemple : 5 of Hearts pour le 5 de cœur ou encore Queen/King of Hearts pour les reines et rois de cœurs. Mais les autres se sont avérés un peu plus difficiles, c'est pourquoi j'ai eu recours à un dictionnaire en ligne, je les ai ensuite recopiés dans mon carnet pour pouvoir bien m'en souvenir. Après les deux heures de cours, j'ai pris quelques cartes au hasard et je me suis entrainé à les décrire. J'ai fait de même le lendemain et quelques jours après le cours pour être sûre de m'en rappeler sur le long terme ». 
16. "Après avoir complété le "self assessment oral communication strategies", je me suis rendu compte que je n'ai jamais pensé à me concentrer sur le verbe et le sujet de la phrase pour comprendre les grandes lignes, j'essaye toujours de comprendre la phrase dans son intégralité. De plus je n'incite pas la personne avec qui je parle explicitement de ralentir son débit ou bien d'utiliser des mots plus faciles ».

17. «En fait, j’ai pu retenir la règle des adjectifs composés qui est la suivante : l'adjectif composé est généralement composé de deux éléments. Le premier élément sert à préciser le sens du second. Ce second élément est un participe passé dans les exemples cités ci-dessus. La première partie des adjectifs composés n'est pas compliqué à retenir. C'est la deuxième partie que j'essaye de retenir pour pouvoir composer plusieurs adjectifs : Par exemple : On peut associer 'badly' ou 'well à timed' pour avoir deux adjectifs différents ».

18. "En conversant et en écoutant les autres, j'ai pu enrichir un peu plus mon vocabulaire ».

19. «Ce matin alors que j'étais en route pour le travail j'ai vu du gel sur le pare-brise d'une voiture, à la suite de quoi je me suis posé la question "Comment dire pare-brise en anglais?". Après être rentré j'ai donc regardé comment dire ce mot à l'aide de Oxford Learner's Dictionary ».

20. «Ce cours m'a permis de faire un tri parmi les techniques d'apprentissages qui me font le mieux apprendre : la technique qui consiste à apprendre sous forme de jeu en fait définitivement partie. Nous sommes autonomes, elle nous stimule et nous fais apprendre tout en nous amusant. Et sur le long terme, j'ai remarqué que prendre conscience de mes erreurs que ce soit par moimême ou par un camarade, m'a fait mieux me souvenir des corrections par la suite ».

\section{ABSTRACTS}

This article looks at L2 vocabulary learning from the learner's perspective. Qualitative data was collected in France from nine Master's level EFL learners' weekly comments in learning diaries. The students, a heterogenous group, commented on their interactive classroom activities (games) and their self-reflexive learning. Our analysis of the data focused on three emergent dimensions: vocabulary building, vocabulary learning strategies and evolutionary attitudes towards their learning. The data suggests that game playing in English contributed to the development of their repertoire of vocabulary building strategies, and overall motivation. As such, the knowledge gained from the learners' diaries has implications for EFL theory and practice and it could prompt teachers to emphasize vocabulary learning and use, in meaningful interactive situations.

Cet article examine l'apprentissage du vocabulaire en L2 du point de vue de l'apprenant. Nos données qualitatives ont été recueillies en France à partir des commentaires hebdomadaires faits par neuf apprenants de l'anglais de niveau Master dans leurs journaux d'apprentissage. Les étudiants, de niveau hétérogène, ont rendu compte du contenu du cours, de leurs activités interactives en classe (sous forme de jeux) et de leur analyse réflexive sur leurs apprentissages. Notre analyse des données s'est concentrée sur trois dimensions émergentes : la construction du vocabulaire, les stratégies d'apprentissage du vocabulaire et l'évolution de leurs attitudes envers leur apprentissage. Les données indiquent que les jeux pendant lesquels la langue étrangère était pratiquée ont conduit à un développement de leur répertoire de stratégies mises en place pour acquérir du lexique ainsi que de leur motivation. Leur assurance lors des activités en interaction orale s'est également améliorée. Les connaissances acquises à partir des journaux des apprenants 
viennent informer les connaissances théoriques et pratiques sur l'apprentissage des langues étrangères en milieu exolingue. Ces données pourraient inciter les enseignants à mettre davantage l'accent sur l'apprentissage et l'utilisation du vocabulaire, dans des situations interactives signifiantes.

INDEX

Mots-clés: vocabulaire, stratégies d'apprentissage, journal auto-réflexif, autonomie, interaction

\section{AUTHORS}

\section{PASCALE MANOIILOV}

Université Paris Nanterre

pascale.manoilov@parisnanterre.fr

\section{NICOLE DIVOUX-RINGUETTE}

Université Paris Nanterre

nicole.d@parisnanterre.fr 